\title{
Radiological Score in Malnourished and Well-nourished Children with Active Rickets
}

\author{
O Fidan, H Alp, Z Orbak, C Karakelleoglu
}

\begin{abstract}
Nutritional rickets and malnutrition are common problems in developing countries. We evaluated the radiological parameters in malnourished and also well-nourished children with active rickets and investigated their response to vitamin D treatment.

The study population consisted of 99 children with rickets, aged 3-30 months and of this number 73 were malnourished and 26 were well-malnourished. The patients were treated with a single dose of 300000 IU of vitamin D and oral calcium, intramuscularly. In addition, malnourished children were nutritionally rehabilitated. Radiographic evaluation was performed by using X-rays of the wrist and knee. Radiographic scoring method defined by Thacher et al was used for the assessment of the severity of the nutritional rickets that was observed.

No statistically significant difference in the radiological scores among the three groups of malnourished children and the well-nourished children with rickets was observed. However, radiological scores for all groups of patients decreased significantly at the $12^{\text {th }}$ week after treatment. The initial radiographic scores of rickets correlated with serum alkaline phosphatase (ALP) concentrations. Radiological evidence and the healing process were similar in both the well-nourished and malnourished groups with rickets. We also recommend that radiological follow-up duration should be extended to at least 12 weeks.
\end{abstract}

Keywords: Malnutrition, radiological score, rickets, vitamin D treatment

\section{Puntuación Radiológica en Niños Malnutridos y Bien Nutridos con Raquitismo Activo \\ O Fidan, H Alp, Z Orbak, C Karakelleoglu \\ RESUMEN}

El raquitismo nutricional y la malnutrición son problemas comunes en los países en desarrollo. Evaluamos los parámetros radiológicos en niños malnutridos y también en niños bien nutridos con raquitismo activo, e investigamos su respuesta al tratamiento con vitamina $D$. La población de estudio consistió en 99 niños de 3 a 30 meses de edad con raquitismo. De este número, 73 estaban malnutridos y 26 bien alimentados. Los pacientes fueron tratados con una sola dosis intramuscular de 300000 unidades internacionales (IU) de vitamina D y calcio oral. Además, los niños malnutridos fueron rehabilitados nutricionalmente. La evaluación radiográfica fue realizada usando radiografías de la muñeca y la rodilla. El método de puntuación radiográfica definido por Thacher et al, se usó para evaluar la severidad del raquitismo nutricional observado. 
No se observó diferencia estadísticamente significativa alguna en las puntuaciones radiológicas entre los tres grupos de niños malnutridos y los niños bien nutridos con raquitismo. Sin embargo, las puntuaciones radiológicas para todos los grupos de pacientes disminuyeron significativamente en la semana 12 tras del tratamiento. Las puntuaciones radiográficas iniciales de raquitismo guardaron correlación con las concentraciones de fosfatasa alcalina sérica (FAS). La evidencia radiológica y el proceso curativo fueron similares en los grupos bien nutridos y malnutridos con raquitismo. También recomendamos que la duración del seguimiento radiológico se extienda al menos 12 semanas.

Palabras clave: Malnutrición, puntuación radiológica, raquitismo, tratamiento con vitamina D

\section{West Indian Med J 2017; 66 (6): 617}

\section{INTRODUCTION}

Rickets results from impaired mineralization of the osteoid tissue of skeleton and it is usually describe as a disease of rapidly growing long-bones. Deficiency of vitamin D may cause nutritional rickets, which is a important health problem especially in developing countries. Nutritional rickets is not a rare problem among children in our country.

Radiological changes of active rickets are evident at the physis (the growth plate) of growing long-bones and the cartilage cells and unmineralized osteoid tissue accumulate in epiphyseal growth plate. There are widening metaphysis and physis, cupping and fraying of the physis. Other radiological findings of rickets are osteopaenia, fracture and curving of long-bones (1).

Serum 25-OH-D3 levels were found to be significantly lower in malnourished children also without rickets than those of well-nourished children (2). It was suggested that cutaneous synthesis of vitamin D may be impaired in protein-energy malnutrition (PEM) and/or it may be related to a defective conversion of the vitamin $\mathrm{D}$ to active metabolites (2). Protein-energy malnutrition may be a cause of the development of rickets.

Although there are many studies reporting prevalence, risk factors, treatment modalities of nutritional rickets, studies reporting radiographic healing of nutritional rickets were found limited in the literature.

We aimed to compare the response to vitamin D treatment by using the radiographic parameters between malnourished and well-nourished children with rickets.

\section{MATERIALS AND METHODS}

Thirty-two patients of 131 patients with nutritional rickets were excluded from the study because of not going to controls. Ninty-nine patients were presented with entirely typical clinical signs and biochemical features of nutritional rickets for this study. Patients who were diagnosed for rickets, did not receive any treatment prior to presentation. Their ages were between six and 30 months. Patients were divided into two groups according to the nutritional status: well-nourished and malnourished groups.

Well nourished group consisted of 26 infants with only rickets. Several classifications of nutritional status based on anthropometric indices have been used. The well-known and most commonly used indicator for malnutrition include, Gomez's criteria of classifying weight-for-age loss according to the per cent deficit [mild: -10 to $-25 \%$ of the reference; moderate: -26 to $-40 \%$ of the reference; severe: below $-40 \%$ of the reference] $(3,4)$. So, 73 malnourished patients with rickets were divided into three group: 23 mild, 28 moderate and 22 severe malnourished patients with rickets.

Weights were measured using the same equipment, by the same observer. Weight was measured to the neares $10 \mathrm{~g}$ using a digital electronic instrument (Seca 727 Digital Baby Scale, serial interface RS 232, Seca Corporation, Vogel\&Holke, Germany). Subjects were naked when weight. Intra-observer differences were of the order of $\pm 5 \%$ and were not statistically significant.

A fasting venous blood sample was withdrawn for biochemical analysis at the diagnosis. Posteroanterior radiographs of the wrists and knees were obtained for all patients. We used a 10-point radiographic scoring method for rickets developed by Thacher et al (5). Changes in the radius and ulna were graded according to the presence of fraying and irregularity of the metaphyseal magrin and by the degree of concave cupping. The femur and tibia were scored by the degree of lucency and widening of the zone of provisional calcification and according to the proportion of the growth plate affected (5). Each radiography was scored by same physician. 
Radiographic changes in rickets were evaluated using the Thacher radiographic scoring method from grade 0 [normal] to grade 3 [severe] (5).

The wrist and knee radiographies were repeated for all rachitic children four, eight and 12 weeks after treatment. Radiological improvement on the repeated wrist and knee X-rays was considered when a well calcified among margin of metaphysis and physis.

All infants with rickets were given 300000 IU vitamin D intramuscular injection once and $75 \mathrm{mg} / \mathrm{kg} /$ daily calcium lactate orally for one-week, in addition to nutritional rehabilitation in malnourished children.

Informed consent was obtained from parents. This study was approved by the Ethics Committee of the Faculty of Medicine, Atatürk University.

Statistical analysis was conducted with the SPSS/PC programme, version 13.0. Variables were evaluated by Chi-square and Kruskal Wallis $\mathrm{H}$ and Spearman test. A $p$-value of $<0.05$ was considered significant.

\section{RESULTS}

The mean ages of all groups were given in Table 1 . There was no statistically significant difference between the groups in terms of mean age $(p>0.05)$. When distribution of gender was evaluated Table 2, it was found that no statistically significant difference was between the groups in gender $(p>0.05)$.

Anthropometric measurements and biochemical parameters at the admission were shown in Table 3. There was statistically significant difference between the groups in anthropometric measurements $(p<0.001)$. Biochemical parameters improved in all groups at the $12^{\text {th }}$ week after treatment.

Table 4 summarized the radiographic findings in the three malnourished groups with rachitic and wellnourished rachitic children. No statistically significant difference was found in the radiological scores among the three groups malnourished children with rickets and the well-nourished children with rickets. However, for

Table 1: The mean age of all groups

\begin{tabular}{lccc}
\hline Groups & n & $\begin{array}{c}\text { Age } \\
\text { (month) }\end{array}$ & $\begin{array}{c}\text { The mean age } \\
\text { (month) } \pm \text { SD }\end{array}$ \\
\hline $\begin{array}{l}\text { Well-nourished children with rickets } \\
\begin{array}{l}\text { Control group) } \\
\text { Mild-malnourished children with rickets }\end{array}\end{array}$ & 26 & $3-22$ & $8.6 \pm 5.0$ \\
$\begin{array}{l}\text { Moderate-malnourished children with } \\
\text { rickets }\end{array}$ & 28 & $3-24$ & $9.3 \pm 5.7$ \\
$\begin{array}{l}\text { Severe malnourished children with } \\
\text { rickets }\end{array}$ & 22 & $3-13$ & $7.1 \pm 3.0$ \\
$p$-value & & \multicolumn{2}{c}{$p=0.629$} \\
\hline
\end{tabular}

Table 2: Distribution of gender for all groups

\begin{tabular}{lccccc}
\hline Groups & \multicolumn{2}{c}{ Male } & \multicolumn{2}{c}{ Female } \\
& $\mathbf{n}$ & $\mathbf{\%}$ & $\mathbf{n}$ & $\mathbf{\%}$ \\
\hline $\begin{array}{l}\text { Well-nourished children with rickets } \\
\text { (Control group) }\end{array}$ & 21 & 80.8 & 5 & 19.2 \\
Mild-malnourished children with rickets & 13 & 56.5 & 10 & 43.5 \\
Moderate-malnourished children with rickets & 14 & 50 & 14 & 50 \\
Severe malnourished children with rickets & 11 & 50 & 11 & 50 \\
$p$-value & \multicolumn{3}{c}{$p=0.007$} \\
\hline
\end{tabular}

Table 3: The mean bodyweight and height measurements of all groups at the admission

\begin{tabular}{lccccc}
\hline & Well-nourished & Mild-malnourished & Moderate-malnourished & Severe-malnourished & $\boldsymbol{p}$-value \\
\hline Bodyweight $(\mathrm{kg})$ & $8.9 \pm 2.1$ & $7.5 \pm 1.3$ & $5.9 \pm 1.2$ & $4.3 \pm 0.9$ & $<0.001$ \\
Bodyheight (cm) & $69.5 \pm 7.5$ & $67.9 \pm 5.9$ & $63.5 \pm 5.0$ & $58.6 \pm 5.2$ & $<0.001$ \\
Calcium (mg/dL) & $7.3 \pm 1.8$ & $7.5 \pm 1.5$ & $7.1 \pm 1.8$ & $7.7 \pm 1.5$ & $>0.05$ \\
Phosporus (mg/dL) & $4.5 \pm 1.1$ & $4.4 \pm 1.2$ & $3.6 \pm 1.6$ & $3.4 \pm 1.3$ & $<0.01$ \\
ALP (IU/L) & $1719 \pm 1058$ & $1422 \pm 454$ & $1612 \pm 728$ & $1157 \pm 898$ & $<0.01$ \\
PTH (pg/mL) & $235.4 \pm 165.2$ & $157.7 \pm 81.5$ & $295.6 \pm 221.5$ & $188.2 \pm 103.1$ & $>0.05$ \\
$25(\mathrm{OH})$ D $(\mathrm{ng} / \mathrm{mL})$ & $4.7 \pm 2.9$ & $4.1 \pm 2.8$ & $4.8 \pm 2.6$ & $4.4 \pm 2.4$ & $>0.05$ \\
\hline
\end{tabular}

ALP: alkaline phosphatase; PTH: parathyroid hormone; 25(OH) D: serum25-hydroxyvitamin D

Table 4: The radiological scores of all rachitic groups

\begin{tabular}{lccccc}
\hline $\begin{array}{l}\text { Radiological } \\
\text { score }\end{array}$ & $\begin{array}{c}\text { Well-nourished } \\
(\mathbf{n = 2 6 )}\end{array}$ & $\begin{array}{c}\text { Mild-malnourished } \\
(\mathbf{n = 2 3})\end{array}$ & $\begin{array}{c}\text { Moderate-malnourished } \\
(\mathbf{n = 2 8})\end{array}$ & $\begin{array}{c}\text { Severe-malnourished } \\
(\mathbf{n = 2 2})\end{array}$ & $\boldsymbol{p}$-value \\
\hline Baseline & $5.0 \pm 1.8(2-10)$ & $5.0 \pm 1.7(2-8)$ & $6.0 \pm 2.7(2-10)$ & $5.2 \pm 2.8(1-10)$ & $p=0.687$ \\
$4^{\text {th }}$ week & $2.3 \pm 2.3(0-8)$ & $2.3 \pm 1.8(0-6)$ & $3.4 \pm 3.0(0-8)$ & $2.4 \pm 2.6(0-8)$ & $p=0.514$ \\
$8^{\text {th }}$ week & $1.7 \pm 1.3(0-4)$ & $1.9 \pm 1.2(0-4)$ & $2.7 \pm 1.8(0-6)$ & $1.9 \pm 1.4(1-4)$ & $p=0.459$ \\
$12^{\text {th }}$ week & $1.0 \pm 1.0(1-1)$ & $0.5 \pm 0.7(0-1)$ & $1.3 \pm 1.4(0-4)$ & $1.0 \pm 0.0(1-1)$ & $p=0.850$ \\
$p$-value & $<0.001$ & $<0.001$ & $<0.001$ & $<0.001$ & \\
\hline
\end{tabular}


Figs. 1-4: showed progression of radiological scores after treatment in each group.

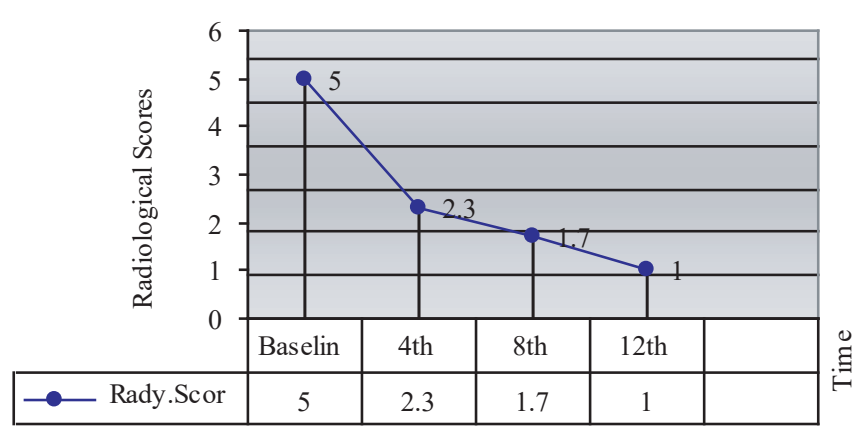

Fig. 1: Radiological scores of the well-nourished children with rickets after treatment.

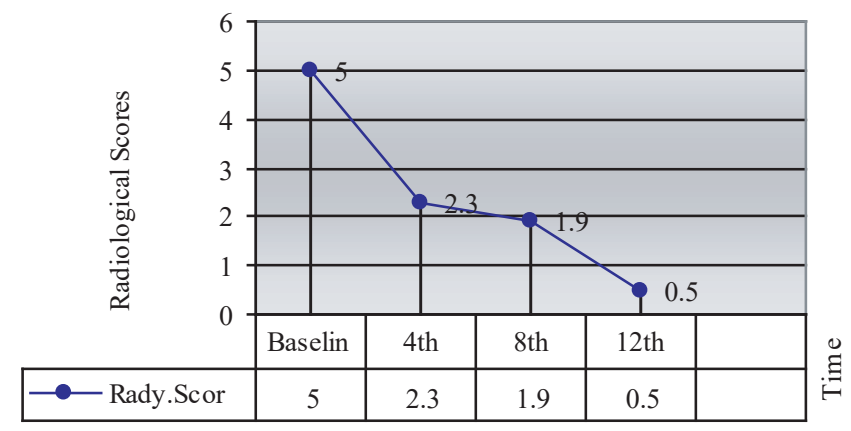

Fig. 2: Radiological scores of the mild-malnourished children with rickets after treatment.

all groups radiological scores decreased significantly at the 12 th week after treatment.

All patients have radiographic findings at the admission. Table 5 showed grades of radiological changes in well-norished and malnourished groups with rickets. Malnutrition did not significantly affect grades of radiological changes at neither admission nor follow-up.

At the $4^{\text {th }}$ week and $12^{\text {th }}$ week, recovery rates of grades in all groups were given in Table 6. When all patients with rickets were evaluated together, radiological grade in $40 \%$ of patients with rickets improved at the $4^{\text {th }}$ week and it did not improve in $5 \%$ of patients at the $12^{\text {th }}$ week after treatment.

The initial radiological scores of the well-nourished and malnourished children with rickets significantly correlated with serum alkaline phosphatase (ALP) levels $[p<0.01]$ (Figs. 5-6), but not serum calcium and phosphorus levels.

\section{DISCUSSION}

Rickets is a syndrome resulting from defective mineralization of the osteoid tissue. The clinical and radiographic spectrum in rickets is extremely variable, depending on the age, the aetiology and the duration and severity of

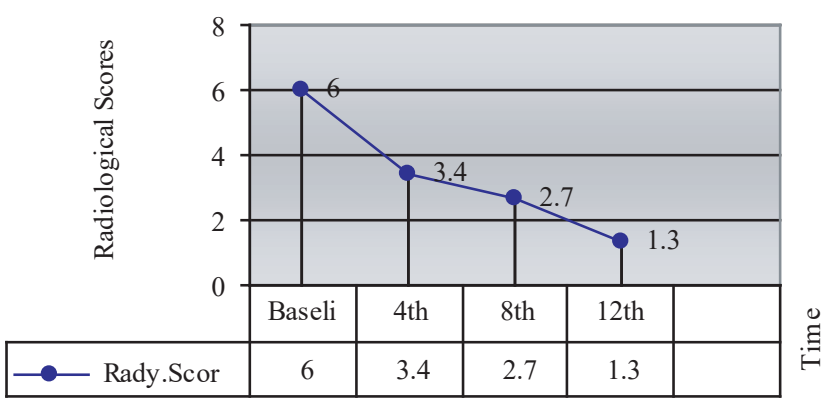

Fig. 3: Radiological scores of the moderate-malnourished children with rickets after treatment.

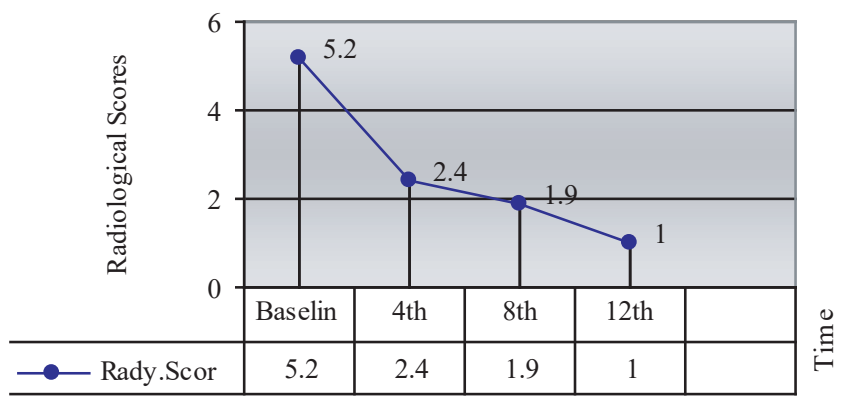

Fig. 4: Radiological scores of the severe-malnourished children with rickets after treatment.

the mineralization defect (6). On the other hand, growth at the end of the long-bones in PEM can slow or arrest. A reduction of cortical bone mass and osteoporosis could result from increased subperiosteal deposition of poorly mineralized bone and still greater endosteal resorption of bone (6-8).

Thacher et al (5) reported radiographic scoring method for the assessment of the severity of nutritional rickets in 2000. This score progresses in half-point increments from zero (normal) to 10 points (severe), because it is practical and not too cumbersome for day-to-day use by physiciants (5), we use this scoring system.

In our study, all patients have radiographic findings at the admission. Radiological grade in $40 \%$ of patients with rickets improved at the $4^{\text {th }}$ week and it did not improve in $5 \%$ of patients at the $12^{\text {th }}$ week after treatment. Siddiqui and Rai (9) reported that radiological signs of rickets were present in $85 \%$ children and findings reverted to normal in all cases after vitamin $\mathrm{D}$ supplementation. In another study, patients with rickets were treated with just orally calcium lactate (350 $\mathrm{mg}$ elemental $\mathrm{Ca}$ /daily) and it was found that the mean radiological score at presentation improved from 3.3 to 1.7 after three months of treatment and to 0.9 after six 
Table 5: Grades of radiological changes in well-nourished and malnourished groups with rickets

\begin{tabular}{|c|c|c|c|c|c|}
\hline $\begin{array}{l}\text { Radiological } \\
\text { score }\end{array}$ & $\begin{array}{l}\text { Well-nourished } \\
\quad(n=26)\end{array}$ & $\begin{array}{l}\text { Mild-malnourished } \\
\quad(\mathrm{n}=\mathbf{2 3})\end{array}$ & $\begin{array}{l}\text { Moderate-malnourished } \\
\qquad(\mathrm{n}=\mathbf{2 8})\end{array}$ & $\begin{array}{l}\text { Severe-malnourished } \\
\qquad(\mathrm{n}=\mathbf{2 2})\end{array}$ & $p$-value \\
\hline \multicolumn{6}{|l|}{ Baseline } \\
\hline Grade 0 & 0 & 0 & 0 & 0 & \multirow{4}{*}{$>0.05$} \\
\hline Grade 1 & 13 & 10 & 12 & 12 & \\
\hline Grade 2 & 10 & 11 & 6 & 5 & \\
\hline Grade 3 & 3 & 2 & 10 & 5 & \\
\hline \multicolumn{6}{|l|}{$4^{\text {th }}$ week } \\
\hline Grade 0 & 11 & 9 & 8 & 12 & \multirow{4}{*}{$>0.05$} \\
\hline Grade 1 & 10 & 11 & 11 & 6 & \\
\hline Grade 2 & 4 & 3 & 4 & 2 & \\
\hline Grade 3 & 1 & 0 & 5 & 2 & \\
\hline \multicolumn{6}{|l|}{$8^{\text {th }}$ week } \\
\hline Grade 0 & 7 & 6 & 9 & 6 & \multirow{4}{*}{$>0.05$} \\
\hline Grade 1 & 8 & 8 & 8 & 4 & \\
\hline Grade 2 & 0 & 0 & 2 & 0 & \\
\hline Grade 3 & 0 & 0 & 1 & 0 & \\
\hline \multicolumn{6}{|l|}{$12^{\text {th }}$ week } \\
\hline Grade 0 & 7 & 7 & 9 & 3 & \multirow{4}{*}{$>0.05$} \\
\hline Grade 1 & 1 & 1 & 2 & 1 & \\
\hline Grade 2 & 0 & 0 & 0 & 0 & \\
\hline Grade 3 & 0 & 0 & 0 & 0 & \\
\hline
\end{tabular}

Table 6: Recovery rates of grades in all groups at the $4^{\text {th }}$ week and $12^{\text {th }}$ week

\begin{tabular}{|c|c|c|c|c|c|}
\hline Radiological score & $\begin{array}{l}\text { Well-nourished } \\
(\mathbf{n}=\mathbf{2 6}) \\
\mathbf{n}(\%)\end{array}$ & $\begin{array}{c}\text { Mild-malnourished } \\
(\mathbf{n}=\mathbf{2 3}) \\
\mathbf{n}(\%)\end{array}$ & $\begin{array}{c}\text { Moderate-malnourished } \\
(\mathrm{n}=\mathbf{2 8}) \\
\mathrm{n}(\%)\end{array}$ & $\begin{array}{c}\text { Severe-malnourished } \\
(\mathbf{n}=\mathbf{2 2}) \\
\mathbf{n}(\%)\end{array}$ & $p$-value \\
\hline \multicolumn{6}{|l|}{$4^{\text {th }}$ week } \\
\hline Grade 0 & $11(42.3)$ & $9(39.1)$ & $8(28.6)$ & $12(54.5)$ & \multirow{2}{*}{$>0.05$} \\
\hline Grade $1+2+3$ & $15(57.3)$ & $14(60.9)$ & $20(71.4)$ & $10(45.5)$ & \\
\hline \multicolumn{6}{|l|}{$12^{\text {th }}$ week } \\
\hline Grade 0 & $25(96.2)$ & $22(95.7)$ & $26(92.9)$ & $21(95.5)$ & \multirow{2}{*}{$>0.05$} \\
\hline Grade $1+2+3$ & $1(3.8)$ & $1(4.3)$ & $2(7.1)$ & $1(4.5)$ & \\
\hline
\end{tabular}

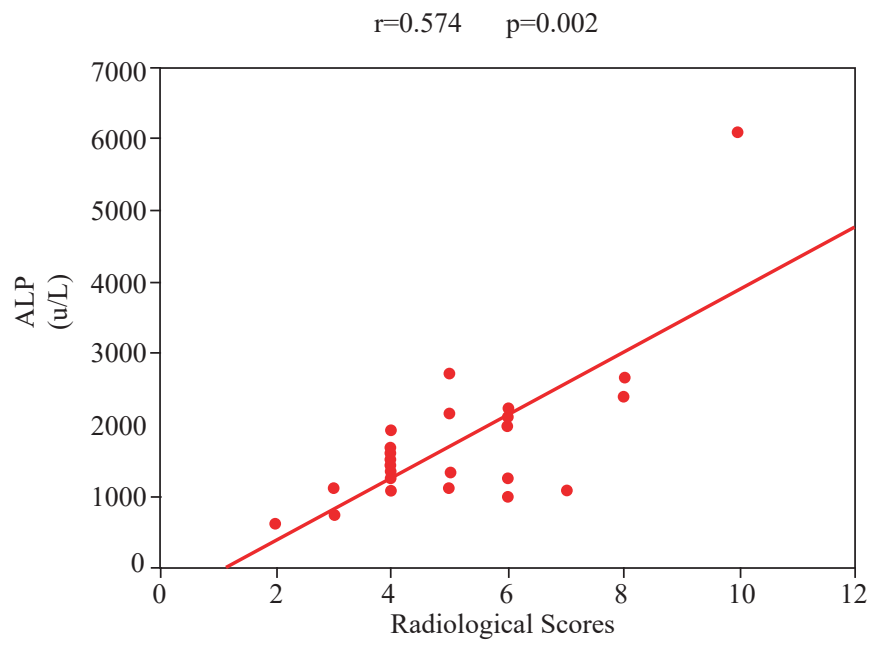

Fig. 5: Correlation between radiological scores and serum alkaline phosphatase in the well-nourished children $(n=26)$ with rickets.

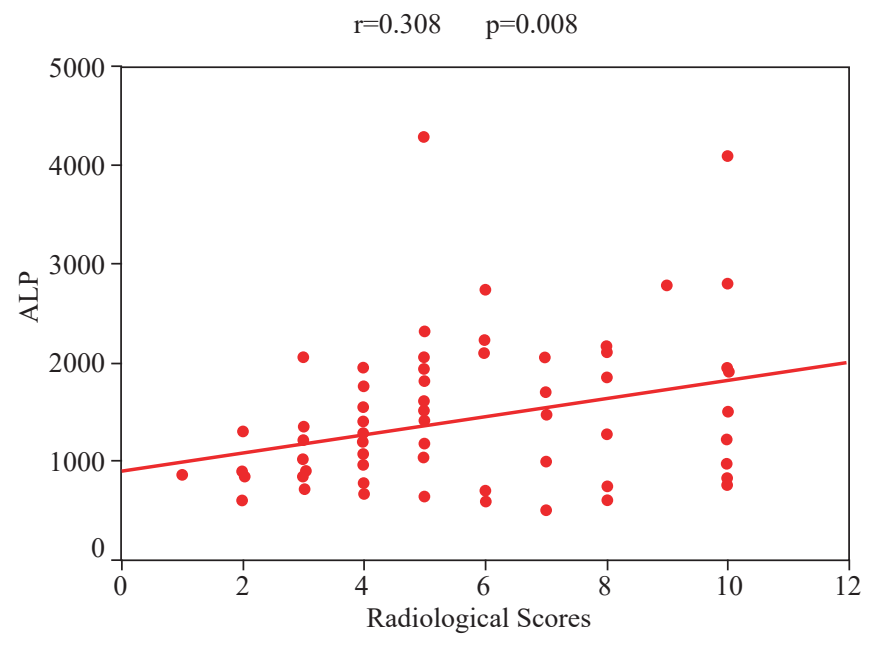

Fig. 6: Correlation between radiological scores and serum alkaline phosphatase in the malnourished children $(n=73)$ with rickets. 
months [according to Arbitrary scoring system, 0-6] (10). This article think that treatment regimen for nutritional rickets in children may be important. Kutluk et al (11) also found that a better clinical and biochemical responses to treatment, was with vitamin $\mathrm{D}$ or in combination with calcium was better than the treatment with calcium alone. Thus, vitamin D therapy in rickets has an important role in radiological healing process when we evaluate the results of reports. In our country, another study reported that the radiological findings completely improved at the $4^{\text {th }}$ week in well-nourished with rickets after vitamin D treatment (12). However, we recommend that follow-up duration may be extended to at least 12 weeks.

Radiologic scores and improvement after treatment, did not differ between well-nourished and malnourished children with rickets in present study. Salimpour (13) reported that the radiological and biochemical changes of rickets might not appear in severe malnutrition until treatment has been instituted with high protein and energy diet and growth is restored. On the other hand, Soliman et al (6) study also showed similar results in malnourished children as a our study. However, they found that the incidence of fractures was higher in the malnourished group with rickets (6) but none of our patients has fracture.

It was reported that the initiall radiographic scores correlated with serum ALP concentration in rachitic children $(5,10)$. Our results showed similar result not only well-nourished children but also malnourished children with rickets. It is known that the elevated ALP denoted active bone metabolism in rachitic children and corresponding with radiological changes as well as the increased osteoid size. On the other hand, ALP levels were higher in the well-malnourished group than those moderate and severe-malnourished groups with rickets. It may be related to lower zinc levels in malnourished children. This correlation between ALP levels and radiological scores is protected even in malnourishen children with rickets. High serum ALP levels is an indication of active disease and radiological score of rickets.

In conclusion, radiological evidences and healing process of rickets were similar in both the well-nourished and malnourished groups with rickets. We also recommend that radiological follow-up duration may be extended to at least 12 weeks.

\section{REFERENCES}

1. Plotkin H, Lifshitz F. Rickets and osteoporosis. In: Pediatric Endocrinology Lifshitz F (ed), $5^{\text {th }}$ ed, Informa Healthcare, New York, 2007; 556-82.

2. Raghuramulu N, Reddy V. Serum 25-hydroxy-vitamin D levels in malnourished children with rickets. Archives of Disease in Childhood 1980; 55: 285-7.

3. Nelson-Barness LA, Curan JS. Nutritional disorders. In: Behrman RE, Kliegman RM, Arvin AM (eds), Nelson Textbook of Pediatrics. WB Saunders, Philadelphia, 1996; 166-9.

4. Gómez-Santos F. Desnutrición Bol Med Hosp Infant Mex 1946; 3: 543-51.

5. Thacher TD, Fischer PR, Pettifor JM, Lawson JO, Manaster BJ, Reading JC. Radiographic scoring method for the assessment of the severity of nutritional rickets. J Trop Pediatr 2000; 46: 132-9.

6. Soliman AT, Madina EH, Morsi MR. Radiological, biochemical, and hormonal changesin malnourished children with rachitic manifestations. J Trop Pediatr 1996; 42: 34-7.

7. Adam P, Berridge ER. Effects of kwashiorkor on cortical and trabecular bone. Arch Dis Child 1969; 44: 705-9.

8. Reichman P, Stein H. Radiological features noted on plain radiographs in malnutrition in African Children. Br J Radiol 1968; 44: 296-9.

9. Siddiqui TS, Rai MI. Presentationand predisposing factors of nutritional rickets in children of Hazara Division. J Ayub Med Coll Abbottabad 2005; 17: 29-32.

10. Oginni LM, Sharp CA, Badru OS, Risteli J, Davie MW, Worsfold M et al. Radiological and biochemical resolution of nutritional rickets with calcium. Arch Dis Child 2003; 88: 812-7.

11. Kutluk G, Cetinkaya F, Basak M. Comparisons of oral calcium, high dose vitamin $\mathrm{D}$ and a combination of these in the treatment of nutritional rickets in children. J Trop Pediatr 2002; 48: 351-3.

12. Tezic T, Yildiz S, Gedik Y, Kazancioglu S, Nuhoglu A. Malnutrisyonlu Çocuklarda Nutrisyonel Raşitizm Tedavisi. Çocuk Sağlığı ve Hastalıkları Dergisi 1986; 29: 301-6.

13. Salimpour R. Rickets in Tehran. Study of 200 cases. Arch Dis Child 1975; 50: 63-6. 